Du texte à la scène : langages du théâtre

\title{
Acting Leontes
}

\section{Patrick Stewart}

\section{(2) OpenEdition \\ Journals}

Electronic version

URL: http://journals.openedition.org/shakespeare/482

DOI: $10.4000 /$ shakespeare.482

ISSN: 2271-6424

\section{Publisher}

Société Française Shakespeare

\section{Printed version}

Date of publication: 1 November 1983

Number of pages: 251-259

\section{Electronic reference}

Patrick Stewart, "Acting Leontes », Actes des congrès de la Société française Shakespeare [Online], 4 | 1983, Online since 01 January 2007, connection on 06 May 2019. URL : http:// journals.openedition.org/shakespeare/482 ; DOI : 10.4000/shakespeare.482 
SOCIETE FRANÇAISE SHAKESPEARE

Actes du Congrès 1982

\section{DU TEXTE A LA SCENE : Langages du Théâtre}

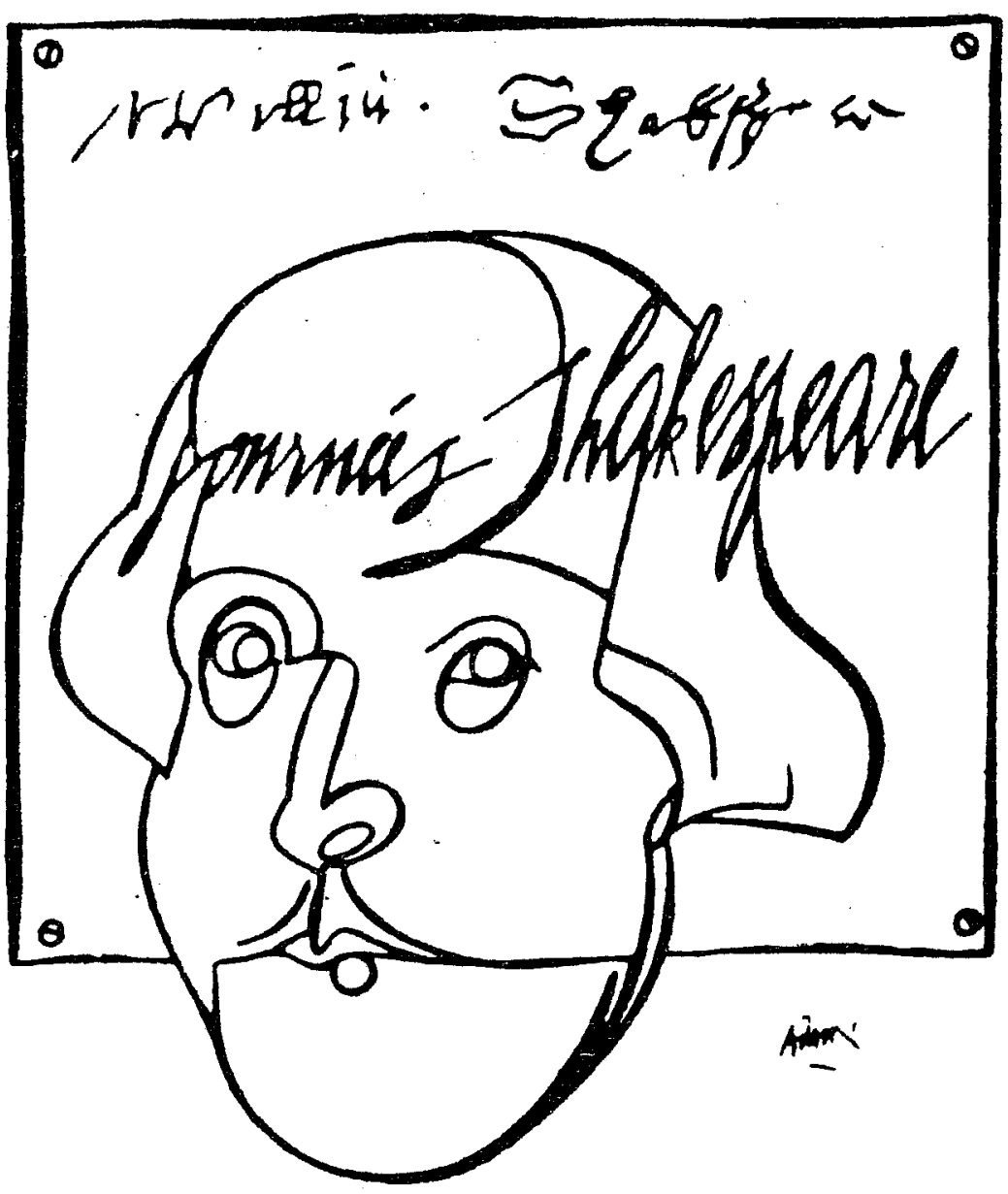

DiRecteur de la publication M.T. Jones - Davies

Publié avec le concours du Centre National de la Recherche Scientifique

JEAN TOUZOT Libraire - Editeur

38 , rue Saint-Sulpice 75278 PARIS CEDEX 061983 


\section{PATRICK STEWART : «ACTING LEONTES»}

The Winter's Tale has never been a very popular play with theatre-goers. The role of Leontes has not attracted actors who have been looking for a vehicle with which to make a reputation. Actors who have played it think the part is unquestionably a "pig». Leontes loses the spectators' sympathy in the first section of the play; he is absent from the central section; and in the final section, he often comes dangerously close to self-pity, which is fairly disastrous for an actor on stage.

In addition, there are two moments in the play which appear impossible to motivate. Besides, the climactic incident is both unbelievable and ridiculous. It is natural, therefore, to dismiss the play as a fairy-tale with small foundation in reality. And it appears so to critics. Criticism written within the last twelve months shows it. A critic writes : «it is useless to try to rationalize the narrative and the sudden frenzy of Leontes ». Another says : «The story is extremely silly». Still another: «The play is improbable and untidy». And again : «The greatness of Shakespeare would be attested by the fact that his reputation has survived The Winter's Tale».

In Edward's Bond's play Bingo, staging the last three months of Shakespeare's life, Jonson and Shakespeare are drinking together in a local inn; Jonson is cross-examining Shakespeare about his works. Jonson says : «Your recent stuff has been pretty peculiar; what was The Winter's Tale about ? ». Shakespeare says nothing to enlighten Jonson in that imaginary scene. Ben Jonson might have seen a performance of the play in which the actors merely told a fairy story; then, naturally, he was confused and puzzled.

I believe that, as Leontes is the centre of the play, so his character (and behaviour) is firmly rooted in reality; he is psychologically coherent to the extent that a modern audience can follow step by step his desperate descent into obsessional behaviour, persecution,cruelty and self-torture. 
Shakespeare carefully indicates each stage, and leads the actor logically through those difficult transitional moments. The fairy tale must not be overlooked, however, and the play can be presented thus : "Once upon a time, there was a happy king, who had a beautiful wife, a lovely young son, and a very good friend ...» But The Winter's Tale can also appear as a modern clinical study. The two plays run in tandem.

With this play, actors, directors, and designers are doing juggling acts; and specially with the language itself : it is Shakespeare's formalized language, handled by modern actors; a harmony must be found between the language of Shakespeare and the evolution of modern acting techniques.

The Winter's Tale is very close to Oscar Wilde's fairy stories; there is the same elegance, the same wit and the same savage, dark, dangerous element.

Leontes is a jealous king. Why? Shakespeare makes it difficult for us to know why. Othello has Iago and the colour of his skin; King Lear has his stupidity and his daughters to help and abet his stupidity; Macbeth has Lady Macbeth and her ambition. But Leontes, it would seem, has nothing. Of course, the actor playing the part, can find an imaginative justification for Leontes' jealousy : he can create a pre-history of the play for himself. But audiences cannot know anything about it. He can make Leontes' change appear in the course of Act I scene ii when the king exclaims : «Too hot, too hot,» (1. 108). Then, the change comes as something unexplainable; and there is no link with the first lines of the play. The actor can also make him jealous from the beginning of the play. It is even possible to achieve all these things by placing Leontes' breakdown and jealousy into a context carefully laid out for us in many subtle ways; a context that became increasingly apparent to us (the actors) during the rehearsals and the first performances. Shakespeare, I am convinced, means us to be troubled by a host of things that happen during the first hundred and fifty lines of the play. Most 
of what is important in the character of Leontes occurs within those lines. From the moment of his scene with Camillo, Leontes is convinced. If the actor has not done his work by that point, he has little hope of achieving any real unity in his performance.

The Winter's Tale is an excellent example of the way an audience must bend all their attention and concentration on what is going to happen. Very few members of the audience really know what their task is. They think theirs is a passive role; in fact they should be prepared to accept an active role. Any Shakespeare performance requires an alertness of mind and a strength of concentration which is a terrific aid to the actor. When it is there, the quality of the actor's work is immensely greater; so is inner tension. An audience has to listen very hard and watch very closely at the beginning of The Winter's Tale.

Act I scene i can be taken very simply : it establishes the conditions of the story; we are told of two men who have not met for many years and whose friendship is based on a childhood relationship. Camillo makes it clear that there is no question about the strength of the tie

(11. 28-31):

they have seemed to be together, though absent; shook hands as over a vast; and embraced, as it were, from the ends of opposed winds.

We are then ready for the main characters to appear, in Act I, sc.ii;

With Polixenes' speech at the beginning of scene ii, the language shifts to verse (11.1-10):

Nine changes of the watery star hath been

The shepherd's note since we have left our

throne

Without a burden. Time as long again

Would be fill'd up, my brother, with our

thanks;

And yet we should, for perpetuity,

Go hence in debt : and therefore, like a cipher

(Yet standing in rich place) I multiply 
With one «we thank you» many thousand moe That go before it.

In other words : «thanks and good bye»; but that is not what Polixenes says; his opening lines are extraordinary; no one is going to speak in that way in The Winter's Tale again, not until, perhaps, the last scene. We never hear that same formality; that same sense of a man speaking lines that are studied and prepared. Polixenes sounds like a man making a statement for the public ear. Nevertheless, this formality makes us question what we have just heard from Camillo. When we see the two men, we see formality. There is a distance between Polixenes and Leontes : the lines need air, they are not colloquial, not familiar. They are not what we expect from a friend to another. Why does it sound so ? Because it is a formal occasion; but there are other reasons.

In that first speech, the verse is absolutely regular. It rolls on the actor's tongue, and sits comfortably on the audience's ear. The Winter's Tale is a play of enormous contrasts; here, one occurs at the very beginning of the scene. Leontes answers in a very different way (11.9-10):

Stay your thanks a while,

And pay them when you part.

Is it a way to respond to such a formal and generous and rich and studied speech ? There is something curiously off-hand and perfunctory about Leontes' answer. Polixenes in his turn says : «Sir, that's to-morrow»; the change is felt here too. Of course, the formality of the occasion may have been relaxed. What he says has been changed by what Leontes has just answered. The verse is no longer a regular line. Leontes' intrusion into the scene has upset the regularity of Polixenes' expression. The speech regains some of its richness in the next lines spoken by Polixenes; as appears from line 11 to line 14 :

Besides, I have stay'd

To tire your royalty.

But the contrast again is felt with Leontes' (11. 15-16):

We are tougher, brother, 
Than you can put us to't.

Polixenes is soon beginning to talk Leontes'own language :

No longer stay.

There is a bluntness which shows that conflict already appears. What is the situation ? One good friend takes leave of another after a long stay. But the host appears to be entirely insensitive to his guest's need and desires, and even is determined to obstruct them. If they were such good friends, Leontes should understand his friend wants to go. Why is it so ? My purpose, here, is to raise questions, not to give answers.

Leontes has the curiously immature reaction of a child who is not getting what he wants; he shows a deviousness of mind which is childlike (11.18-19):

We'll part the time between's then : and in that I'll no gainsaying.

Polixenes answers (1.19) : «Press me not». There is urgency to leave and almost, perhaps, a sense of fear. At least, we feel a sense of desperation creeping into his speech.

And yet, this is one of the happiest moments of the play. This is before anything started to go wrong. Leontes' (1. 27) «Tongue-tied our queen ?» has terrific resonance; he picks up the image Polixenes has just used ' (1.20):

There is no tongue that moves, none, none, i'th' world,

So soon as yours, could win me :

But Leontes obviously thinks there is.

Hermione is heard for the first time. One might imagine she would be sympathetic to Polixenes' wish to leave. On the contrary, she introduces a competition which is potentially dangerous, especially by her remark : (11.29-30) :

$$
\text { You, sir, }
$$

Charge him too coldly.

$T ! \cdot n$. there is a physicality in the images she uses: (1.33)

He's beat trom his best ward.

and again (1.37):

We'll thwack him hence with distaffs. 
She introduces a sense of competition by the fighting metaphor. She is teasing, but the physicality of the image dominates, her mind. "Well said, Hermione," is the last thing Leontes says for a long time. A problem occurs for the actors : a stage-direction, in some editions, bears : «Leontes draws apart»; does Leontes really go away? If he is absent during the conversation between Polixenes and Hermione, how does the queen say (11. 42-44):

yet, good deed, Leontes

I love thee not a jar o'th' clock behind What lady she her lord.

She may say it reflectively, or throw it over her shoulder at his receding back; in any case, it is a problem for the actress playing Hermione. It is a curious way of expressing her affection. Why does she choose to express her feelings in that way? There is a long exchange between Polixenes and Hermione while Leontes says nothing at all. Does he hear?

Hermione's speech to Polixenes is friendly, but implies criticism. She concludes it with : "You'll stay ?» (1. 44). Polixenes remains adamant «No, madam.» She goes on :

«Nay, but you will?»

He answers :«I may not, verily.» (1.45).

The pressure of the argument goes on. There is a possibility of a conspiracy between Leontes and Hermione; they are both anxious for the same thing : they both want Polixenes to stay, perhaps for different reasons. Are they acting independently ? The guest has become a victim or a referee. We cannot question Polixenes' desire to leave; and yet, she mocks him; in a charming, witty way, but it is mockery, nevertheless (11. 52-53):

Force me to keep you as a prisoner,

Not like a guest :

Here the word «prisoner» is charged with double meaning. It is the first hint of sexuality. Then Polixenes agrees to stay with his best friends; yet he sounds curiously reluc$\operatorname{tant}(1.56)$ : 
Your guest then, madam.

Then she adds (11. 60-61):

Come, I'll question you

Of my lord's tricks, and yours, when you were

boys.

«Tricks»: the word is of astonishing ambiguity; with both

a simple, honest meaning and a deeply sexual hint; tricks are sexual attitudes. By his answer, culminating on : «and to be boy eternal» Polixenes may be trying to tell her mind. Hermione goes on with the series of «double entendre» $(11.65-66)$ :

Was not my lord

The verier wag o' th' two ?

«Wag» is also ambiguous, suggesting as it does, somebody sexually promiscuous. Even in Polixenes' speech sexuality appears. Hermione adds (11.75-76):

By this we gather

You have tripp'd since.

Again, she uses a word with a double meaning. «Trip» means «to fall» and «to be subdued sexually». Polixenes has then a fascinating suggestion : everything was innocent before women appeared on the scene (11.77-80) :

Temptations have since then been born to's : for

In those unfledg'd days was my wife a girl;

Your precious self had then not cross'd the eyes

Of my young play-fellow.

After that, the sexuality of Hermione's speech is out in the open (11.83-86) :

Th'offences we have made you do, we'll answer,

If you first sinn'd with us, and that with us

You did continue fault, and that you slipp'd not

With any but with us.

Her words are highly ambiguous. At that moment, Leontes says (1. 86): «Is he won yet ?» If he was there, he has hcurd Polixenes' answer and need not ask. If, being present, he still has not heard, it opens vistas as to his state of mind when he overhears Hermione's ambiguous words. Leontes then congratulates Hermione. She answers with a 
speech loaded with overt sexuality that reminds us of Antony and Cleopatra; there is voluptuousness and richness in her words (11. 94-96) :

\section{You may ride's}

With one soft kiss a thousand furlongs ere

With spur we heat an acre.

Leontes is talking about his courtship of his wife. The sense of money and value, present through the first part of the scene with Polixenes speaking of his debt, reappears here with the image of the striking of a bargain (11. 102-103):

Three crabbed months had sour'd themselves

Ere I could make thee open thy white hand, to death,

And clap thyself my love;

There is a curious parallelism with Hermione's expression when she mentioned her affection for her husband (11.42 et s.):

I love thee not a jar o'th' clock behind ...

Hermione's answer to Leontes' congratulation is most unfortunate (11. 106-108) :

Why lo you now; I have spoke to th' purpose twice :

The one, for ever earn'd a royal husband;

Th' other, for some while a friend.

Hence, Leontes' aside : «Too hot, too hot !» and the even more disquieting:

my heart dances,

But not for joy - not joy.

The complexity of the three-cornered relationship must make the actor and the director question closely and in detail the exact nature of this relationship.

This very ambiguity, the increasing sensuality of the scene, the contrast of the speech between the two men, Hermione's contribution to the scene, establish a context in which Leontes' breakdown is going to occur. The breakdown is sudden, massive, and entirely overwhelming.

It is possible to play Leontes as a man who becomes suddenly jealous, or as a man who is jealous all the way through. There is a tension underneath the scene; the 
Du Texte à la Scène :Langages du Théâtre. 259

actors have to respond to the complexity of what Shakepeare is trying to say. Something profound is happening to all those three characters which will scar them and lead them to waste sixteen years of their lives. A critic wrote about the end : "The years have left their mark on both of them, and also on us their audience».

(All references are to the Arden edition)

10 Octobre 1982 